DIGITAL COMMONS
@ UNIVERSITY OF SOUTH FLORIDA

Volume 11

Issue 1 Summer 2021

\section{ABO: Interactive Journal for Women in the Arts, 1640-1830}

\title{
Review of Women Wanderers and the Writing of Mobility, 1784-1814, by Ingrid Horrocks
}

\author{
Elizabeth Porter \\ Hostos Community College, City University of New York (CUNY), lizporter27@gmail.com
}

Follow this and additional works at: https://digitalcommons.usf.edu/abo

Part of the Feminist, Gender, and Sexuality Studies Commons, and the Literature in English, British Isles Commons

\section{Recommended Citation}

Porter, Elizabeth (2021) "Review of Women Wanderers and the Writing of Mobility, 1784-1814, by Ingrid Horrocks," ABO: Interactive Journal for Women in the Arts, 1640-1830: Vol.11: Iss.1, Article 20. http://doi.org/10.5038/2157-7129.11.1.1253

Available at: https://digitalcommons.usf.edu/abo/vol11/iss1/20

This Reviews is brought to you for free and open access by Digital Commons @ University of South Florida. It has been accepted for inclusion in ABO: Interactive Journal for Women in the Arts, 1640-1830 by an authorized administrator of Digital Commons @ University of South Florida. For more information, please contact digitalcommons@usf.edu. 
Review of Women Wanderers and the Writing of Mobility, 1784-1814, by Ingrid Horrocks

\author{
Abstract \\ A review of Women Wanderers and the Writing of Mobility, 1784-1814 by Ingrid Horrocks. Written by \\ Elizabeth Porter. \\ Keywords \\ mobility, wanderer, form, women writers \\ Creative Commons License \\ (c) (i) (8)
}

This work is licensed under a Creative Commons Attribution-Noncommercial 4.0 License 
Ingrid Horrocks. Women Wanderers and the Writing of Mobility, 1784-1814. Cambridge University Press, 2017. 288 pp. ISBN: 9781316856109.

Reviewed by Elizabeth Porter Hostos Community College, CUNY

The 2017 book Women Wanderers and the Writing of Mobility, 1784-1814 by Ingrid Horrocks draws on the interdisciplinary field of mobility studies to craft a compelling argument about the figure of the woman wanderer in an array of literary genres. Persuading readers that the familiar Romantic figure of the wanderer (popularized by William Wordsworth) has its origins in women's writing of the final decades of the Eighteenth Century, Horrocks's monograph offers a nuanced study of the relationship between "travel, mobility, gender, social interaction, and literary form" (3). Through insightful—and often dazzling - close readings of Charlotte Smith's poetry, Mary Wollstonecraft's travel writing, and novels by Ann Radcliffe and Frances Burney, Horrocks builds a distinctly feminist argument about the complicated and sometimes harrowing ways that women moved, observed, and wrote in a patriarchal social world. On the "level of form as well as trope," Horrocks illustrates how digressions and other forms of textual wandering help to evoke or imagine the conditions and positions of women on the move (35). This monograph fits squarely in the field of British literary studies of the long Eighteenth Century and Romantic period, and its cross-genre investment in the topics of women's writing and mobility will be of interest to the journal's readers.

The introduction of this book sets up the argument and methodology with clarity and polish. In her thesis, Horrocks states that "The elements of subjective crisis concentrated on figures of abject women wanderers has distinctive and important intellectual and textual effects." (35) To make this argument formal as well as tropological, each of the five chapters focuses on a "single, if fluid, genre" to demonstrate how the text wanders in relation to the woman wanderer figure. In a scholarly field where specialists often define their expertise on knowledge of a single genre, the cross-genre scope of this project offers a refreshing departure from the expected and enables a more capacious framework for asking questions about what "formal shifts register and evoke" (30). From the outset of the book, Horrocks distinguishes between wandering and traveling: "Wandering assumes neither destination nor homecoming." As such, the wanderer's narrative works "by digression and detour rather than by direct route" (1). Traveling is a more privileged position imbued with agency, such as when genteel men embarked on the well-documented Grand Tour through Europe. Since it was more exceptional 
for women to travel with any real agency and direction either at home or abroad, "reluctant wanderers" are held up as a more representative focus for literary study. Applying the work of mobility studies scholars such as John Urry and Tim Cresswell to her textual interpretation, Horrocks illustrates how movement is not inherently positive or progressive. While Horrocks excels in close textual analysis, one of her most exciting insights is borne from the methodology of distant reading. Despite the prominence of distressed female travelers throughout the Eighteenth Century, the word 'wander' was used infrequently in literature published before the 1780s, appearing four times more frequently in texts published between 1786 and 1820 than between 1720 and 1785 (28). This finding helps to justify the careful attention paid to literary wanderers and wandering texts in a thirty-year period that bridges the Eighteenth and Nineteenth Centuries.

Chapters 1 and 2 are a boon for scholars of Charlotte Smith's poetry, featuring sustained discussions of The Emigrants (1793) and Elegiac Sonnets (1784). Before moving to a discussion of Smith's poetry, Horrocks examines prospect poems from Alexander Pope, William Cowper, and Oliver Goldsmith, each of which presents a "stabilizing fantasy" from their positions of authority (39). In The Emigrants, Smith recasts Cowper's "version of the poet-observer as the exiled wanderer," which ultimately creates a new iteration of the literary figure of the wanderer for the 1790s (69). Chapter 2 develops this analysis of Smith's woman wanderer but with even greater attention to form. The "repetition and intensification of images of ceaseless difficult movement" build up an "accretion of loss" and showcase the pain of "unanchored mobility" (80). With a particular focus on Sonnets 4, 12, 36, and 44, Horrocks details a kind of endlessness in this sonnet sequence that suggests a "general sense of dislocation and movement without end" (81).

The third chapter is especially evocative with regard to form's function in Ann Radcliffe's novels, particularly The Mysteries of Udolpho (1794). Presenting Radcliffe's gothic heroines as "reluctant wanderers," Horrocks argues that insertions of poetry quotations offer a kind of formal respite from the gothic terror resulting from coerced mobility. In an elegant formulation, Horrocks contends that poetic quotation in Radcliffe is the "inverse of Austenian free-indirect discourse," keeping us outside the character's mind in a protective gesture from the "trauma the gothic plot inflicts" (127). While there was an "interpenetration of genres" in the 1790s whereby novelists often inserted verse in their work, Horrocks persuasively suggests that Radcliffe's quotation of poetry is a narrative strategy to resist interiority (114). 
In her analysis of Mary Wollstonecraft's A Short Residence (1796), Horrocks convincingly demonstrates how the figure of the wanderer operates in this text to unseat assumptions about travel. By representing herself as "embodied, pained, and homeless," Wollstonecraft registers a "radical shift in the position of the traveler," one that is at odds with Enlightenment ideas of travel and empiricism (143). Often decentered from her own story and expressing sympathy for women in more vulnerable or precarious class positions, Wollstonecraft suffers while moving and feeling abroad. Drawing on the field of mobility studies to anchor her literary interpretation, Horrocks speaks of the necessity of unraveling associations between travel and freedom. As to be expected when discussing Wollstonecraft, Horrocks addresses feminism most explicitly in this chapter, challenging the dominant premise of second-wave feminism that "women's escape from the domestic home [is] a sign of liberation" (143). The success of A Short Residence, Horrocks argues, is the performance of the "immense struggle involved in a woman finding both an adequate and a new position from which to feel, speak, and sympathize" (166). There is constant struggle, but no real progress, in this narrative and others explored in the monograph.

In the tour de force fifth chapter of the book, Horrocks maps the wanderings of Frances Burney's final protagonist and explains why the novel appears so unwieldy and digressive. The Wanderer in Horrocks's treatment is a "radical reimagining of how the lives of women could be presented in fiction" (170). Once the protagonist, Juliet, reaches the English shore from France, she is forced to move from one location to the next in an ironic version of a typical tourist itinerary. Through clear subheadings that identify and analyze Juliet's movements in Salisbury, the New Forest, Wilton, and Stonehenge, Horrocks shows how Juliet's wanderings differ distinctly from tour narratives like William Gilpin's, for instance. Such comparative examples support the gendered distinctions between travelers and wanderers that Horrocks sets up from the introduction. Throughout the chapter, Horrocks draws on mobility studies and novel studies to ultimately conclude that Burney's novel "represents an exaggerated version of the experiences of those who do not have access to the privilege that makes traveland its associated experiences - a source of improvement and self-development" (200). She joins conversations about the novel that push back against the idea that the form is synonymous with the bildungsroman or invested in interior depth. This is a productive line of inquiry, one that has been addressed brilliantly in recent monographs such as Stephanie Insley Hershinow's Born Yesterday (2019) and Wendy Anne Lee's Failures of Feeling (2018).

Most of this monograph contains fresh close readings and sparkling prose, yet there are some missed opportunities and oversimplifications. Situating the 
interpretive category of the woman wanderer (all of whom are white and European in Horrocks's examples) among those forced into movement after being colonized or enslaved by the British empire would have helped to frame the global context that is mostly elided in this discussion. By generalizing about women's collective dispossession throughout her study, there is a tendency to collapse distinctions between women who suffer precarity due to their dependent relationships on men and women who would be actually classified as vagrants or impoverished. Finally, the book's organizing framework bookends the contributions of women writers with their male counterparts, as the book begins and ends with discussions of canonical male poets of the Enlightenment and Romanticism. While these touchstones may be useful for understanding the literary history of writing mobility, the choice to begin and end with male voices somewhat detracts from the fascinating interpretations of women's writing at its core.

Overall, though, this book offers an exciting contribution to studies of gendered mobility in literature through its exploration of the woman wanderer. With clear signposting of her argument and scholarly contribution, Horrocks's monograph offers a master class in performing literary criticism across multiple genres and in examining the interplay between trope and form. 